\title{
REVISED Gilles de la Tourette Syndrome: advice in the times of
}

\section{COVID-19 [version 2; peer review: 2 approved]}

\author{
Mary M. Robertson'1, Valsamma Eapen², Renata Rizzo³, Jeremy S. Stern, \\ Andreas Hartmann (iD) 5 \\ ${ }^{1}$ Department of Psychiatry, University College of London, London, W1T-7NF, UK \\ 2University of New South Wales and Academic Unit of Child Psychiatry, Liverpool Hospital and Ingham Institute, Sydney, NSW 2170, \\ Australia \\ ${ }^{3}$ Section of Child and Adolescent Neuropsychiatry, University of Catania, Catania, Italy \\ ${ }^{4}$ Department of Neurology, St George's University of London, London, SW17 0QQ, UK \\ ${ }^{5}$ Department of Neurology, Groupe Hospitalier Pitié-Salpêtrière, Paris, 75013, France
}

\begin{tabular}{l}
\hline V2 First published: 14 Apr 2020, 9:257 \\
https://doi.org/10.12688/f1000research.23275.1 \\
Latest published: 28 Apr 2020, 9:257 \\
https://doi.org/10.12688/f1000research.23275.2 \\
\hline
\end{tabular}

\section{Abstract}

The novel coronavirus disease (COVID-19) was identified as the cause of an outbreak of respiratory disease in China at the end of 2019. It then spread with enormous rapidity and by mid-March 2020 was declared a world pandemic. Gilles de la Tourette Syndrome (GTS) is a childhood-onset neurodevelopmental disorder with a worldwide prevalence of about $1 \%$ of the population. The clinical symptoms include multiple motor and one or more phonic (vocal) tics. Germane to this communication is that $85 \%$ of patients with GTS have associated psychiatric co-morbidities, many of which are being exacerbated in the current global health crisis. In addition, several symptoms of GTS may mimic COVID-19, such as a dry cough and sniffing (phonic tics), while other symptoms such as spitting, inappropriate touching of others and "non-obscene socially inappropriate symptoms" can potentially get patients with GTS into trouble with the law. We suggest that a clear explanation of the COVID-19 illness and GTS is important to enable colleagues of various specialities who tend to patients with GTS. It is important to acknowledge at the outset that the information available on the COVID-19 pandemic changes daily, including cases infected, deaths reported, and how various national health systems are planning and or coping or not. It is fair to say that having read the current medical and lay press we conclude that it is not easy to reassure our patients with absolute certainty. However, notwithstanding that, we hope our documentation is of some assistance.

Keywords

Gilles de la Tourette syndrome, COVID-19, tics, anxiety, OCD, ADHD, confinement

\section{Open Peer Review}

Approval Status

1 2

version 2

(revision)

28 Apr 2020

version 1

14 Apr 2020

1. Kirsten R Müller-Vahı ID, Hannover Medical

School, Hannover, Germany

2. Andrea Cavanna ID, University of

Birmingham, Birmingham, UK

Any reports and responses or comments on the article can be found at the end of the article. 


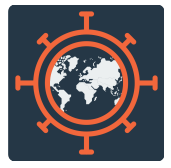

This article is included in the Emerging Diseases

and Outbreaks gateway.

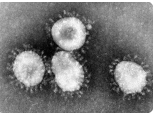

This article is included in the Coronavirus

collection.

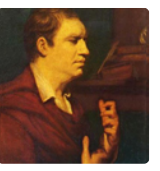

This article is included in the Tics collection.

Corresponding author: Andreas Hartmann (andreas.hartmann@aphp.fr)

Author roles: Robertson MM: Conceptualization, Writing - Original Draft Preparation, Writing - Review \& Editing; Eapen V: Writing Original Draft Preparation, Writing - Review \& Editing; Rizzo R: Writing - Original Draft Preparation, Writing - Review \& Editing; Stern JS: Writing - Original Draft Preparation, Writing - Review \& Editing; Hartmann A: Conceptualization, Writing - Original Draft Preparation, Writing - Review \& Editing

Competing interests: No competing interests were disclosed.

Grant information: The author(s) declared that no grants were involved in supporting this work.

Copyright: ( $\odot 2020$ Robertson MM et al. This is an open access article distributed under the terms of the Creative Commons Attribution License, which permits unrestricted use, distribution, and reproduction in any medium, provided the original work is properly cited. Data associated with the article are available under the terms of the Creative Commons Zero "No rights reserved" data waiver (CCO 1.0 Public domain dedication).

How to cite this article: Robertson MM, Eapen V, Rizzo R et al. Gilles de la Tourette Syndrome: advice in the times of COVID-19

[version 2; peer review: 2 approved] F1000Research 2020, 9:257 https://doi.org/10.12688/f1000research.23275.2

First published: 14 Apr 2020, 9:257 https://doi.org/10.12688/f1000research.23275.1 


\section{REVISED Amendments from Version 1}

We thank the reviewers for their reviews and have incorporated all their comments into version 2 of the paper. Specifically, beyond formal concerns, a reference on the prevalence of coprololia was added (Freeman et al., 2009) and two sentences on telehealth in GTS. However, we have chosen not to include a specific reference on neurologic complications of COVID-19. For now, we prefer to stick to the AAN resource centre link we provided since this is a rapidly moving field, and will likely provide a more panoramic view of the field. Also, it is at present unclear to what extent these complications are causally linked to COVID-19 or correlational, so care is warranted.

Any further responses from the reviewers can be found at the end of the article

\section{Aetiology: COVID-19}

Coronaviruses are a group of viruses that mostly result in mild illnesses, similar to the "common cold", targeting the upper respiratory tract. However, certain types of coronaviruses can affect the lower airway, causing serious illnesses such as bronchitis or pneumonia. Coronaviruses have very large single stranded RNA genomes (approximately 26-32 KB). Coronavirus particles are surrounded by a fatty outer layer called an "envelope" and usually are spherical when visualised under an electron microscope, with a "corona" of club-shaped spikes on their surface (Wu et al., 2020). Most people become infected with coronaviruses at some point in their lives, but the majority of these are harmless. The novel coronavirus, which causes the COVID-19 illness, is different, and can be extremely serious.

The virus that causes COVID-19 is known as SARS-CoV-2 (Severe Acute Respiratory Syndrome Corona Virus 2). It appears to have emerged in Wuhan, Hubei Province, China. The viruses first inhabited animals such as bats and then "jumped" to humans: this occurred in China in late 2019, from whence it has spread worldwide (Zhu et al., 2020). Coronaviruses replicate their RNA genomes using enzymes called RNA-dependent RNA polymerases, which are prone to errors, but genomic analysis to date suggests that SARS-CoV-2 is mutating slowly, thus reducing the chance of it changing to become deadlier (Wu et al., 2020). It is worth mentioning that since 2003, viral diseases have caused major pandemics. These include the coronaviruses, which have caused multiple major public health events that resulted in global pandemics such as severe acute respiratory syndrome (SARS; or "bat SARS"), Middle East respiratory syndrome (MERS) and the current coronavirus disease (COVID-19) (Kandeel et al., 2020). In addition, with a growing threat to maternal-foetal health, the Zika viral illness began in 2009 with devastating consequences and continues to spread (Towers et al., 2018). Finally, in some parts of the globe, cases of swine flu (H1N1 virus) are still on the rise such as in India, where in 2020 alone around 1500 cases have been reported to date, with 28 deaths in the period from 1 January to 1 March 2020.

\section{Clinical features: COVID-19}

COVID-19 can affect individuals of any ages and clinical symptoms may vary. The main recognised clinical features of COVID-19 include fever (52\% of younger patient, $89 \%$ of older patients), cough (44\% younger, $77 \%$ older; usually dry, but can be expectorant), fatigue or tiredness; more severe cases get pneumonia. In mild cases people may have only a runny nose or sore throat. Patients may also have gastro-intestinal symptoms such as nausea, diarrhoea and anorexia. It does appear that older people, on the whole, are more severely affected. Individuals with pre-existing co-morbid conditions also appear to be particularly at risk: these illnesses include hypertension, diabetes, cardiovascular disease, and malignancy (Mao et al., 2020; Wan et al., 2020; Zhang et al., 2020a; Zhang et al., 2020b; Zhang et al., 2020c; Zheng et al., 2020a). There is also recent evidence that anosmia or loss of smell is a symptom of COVID-19 and can even be the presenting symptom (Hopkins \& Kumar, 2020; Luers et al., 2020). Recent unpublished results in a series of 417 patients suggest rates of $>80 \%$, and a large European multicentre trial is currently being undertaken.

Severity has been described in various ways. Patients with abnormal chest images are older, with a higher rate of pre-existing conditions, lower rate of exposure history, and a longer time between onset and confirmation than patients without pneumonia. In addition, patients with more severe symptoms have a higher rate of fever, expectorant cough and headache, lower lymphocytes, albumin and serum sodium, and a higher total bilirubin, c-reactive protein, creatine kinase and lactate dehydrogenase, (Zhang et al., 2020c). Muscle aches, headache, shortness of breath and nausea/vomiting are also associated with disease severity. Also, biomarkers such as lower lymphocyte levels in addition to raised leukocytes, D-dimer levels, procalcitonin and serum creatinine, as well as higher radiograph score at admission are predictive factors for a severe/critical subtype (Zhang et al., 2020c). Finally, it has been shown that elevated exhaustion levels and reduced functional diversity of $\mathrm{T}$ cells in peripheral blood may predict progression in COVID-19 patients (Zheng et al., 2020b). In the most severe cases, patients go into respiratory and multi-organ failure. It must be borne in mind, however, that mortality has also been reported in children, adolescents and young adults. Thus, it does appear that no one is immune or not at risk.

\section{Aetiology and epidemiology: Gilles de la Tourette Syndrome}

Gilles de la Tourette syndrome (GTS) is a complex neurodevelopmental disorder that has aetiological contributions from genetic influences in pregnancy and birth difficulties, and immunological variables (Robertson et al., 2017). Whereas the PANDAS (Pediatric Autoimmune Neuropsychiatric Disorders Associated with Streptococcal Infections) hypothesis is increasingly being discarded, an immunological trigger is possible in a subset of patients with GTS as they might show differences in immune responses compared to controls (Martino et al., 2015); however, how these might possibly affect response to viral infections and, more specifically SARS-CoV-2, remains as yet unknown (see below).

\section{Clinical features: Gilles de la Tourette syndrome}

The generally recognised diagnostic criteria according to the DSM-5 for GTS are multiple motor and at least one or more vocal (phonic) tics over the course of at least 12 months in a patient less than 18 years old (APA, 2013). The phenotypic spectrum also includes chronic (persistent) motor or vocal tic disorder and 
transient (provisional) tic disorder. The most common motor tics are facial (such as eye blinking and grimacing), whereas the most common phonic tics are coughing, sniffing and throat clearing (Robertson et al., 2017). Individuals may have the relatively rare (around 15-20\%) but "press-worthy" symptom of coprolalia (Freeman et al., 2009).

Neuropsychiatric comorbidities are common (around 85\% of patients) and include obsessive-compulsive disorder or behaviours (OCD/OCB), attention-deficit hyperactivity disorder (ADHD), learning disabilities, depression, anxiety, and autism (Rizzo et al., 2014; Robertson et al., 2017).

It is also worth noting that quality of life in patients with GTS has been demonstrated to be reduced (Elstner et al., 2001; Eddy et al., 2011). In addition, Eapen et al. (2016) reviewed the literature, pointing out that both tics and comorbidities in GTS may result in poorer psychosocial functioning. Much of the stigma and social maladjustment associated with GTS resulting in exclusion, bullying and discrimination, can be largely caused by misperceptions of the disorder by teachers, peers and the wider community. Thus, in the current "COVID-19 climate," we must be mindful to remain attuned to the needs of our patients with GTS.

\section{Gilles de la Tourette syndrome in the context of COVID-19}

Potential consequences of the COVID-19 pandemic on patients with GTS can be classified according to four axes:

1. Anxiety related to the pandemic

2. Confinement/quarantine

3. Alterations in tics and behaviours specific to GTS

\section{Neurotropic effects of SARS-CoV-2}

\section{Anxiety related to the pandemic}

Anxiety is a frequent comorbidity in GTS, manifesting both as generalized anxiety as well as specific phobias (Martino et al., 2017). Obviously, the relentless and generally starkly pessimistic media coverage on COVID-19 is likely to exacerbate these anxieties. In young children, their comprehension of the situation is limited, but the transmission of parental anxiety is a possible concern, either because of the pandemic itself and/or the economic consequences they face.

OCD is an equally frequent comorbidity in GTS. In the current era of governmental and public health instructions designed to slow the spread of COVID-19, patients with contamination OCD are at particular risk of experiencing conflicting demands since their baseline cognitive-behavioural training (CBT) (if applicable) asks for less hand washing, the exact opposite of what is now being recommended: this may result in cognitive dissonance which may turn close to unbearable. Obsessions relating to death (one's own or loved ones) will likely also rise, as well as morbid ruminations (Robertson \& Cavanna, 2007), and possibly phenomena typical of GTS such as symmetry and 'just right' behaviours.
In addition, anxiety may trigger an increase in tic severity. It must be explained to patients and parents that this does not reflect an aggravation of GTS per se but is contextual, and thus likely reversible in the foreseeable future. An exacerbation of baseline tics in general may not be inevitable. In normal practice patients sometimes even report a reduction of GTS symptoms in association with major anxiety-provoking life events, although the reverse is conventionally more often true. Aside from OCD, entire populations are now undergoing some kind of "life event", no doubt to be the subject of major study in due course.

\section{Confinement/quarantine}

The psychological sequelae of confinement and quarantine following the COVID-19 outbreak have been well reviewed recently (Brooks et al., 2020). The authors reviewed the psychological impact of quarantine using three data bases and 3166 papers out of which 24 were included. Most studies reviewed reported negative psychological effects including post-traumatic stress symptoms, confusion and anger. Stressors included longer quarantine duration, infection fears, frustration, boredom, inadequate supplies, inadequate information, financial loss and stigma. Some researchers suggested a long-lasting impact.

As with anxiety - since confinement and quarantine are anxietytriggering in their own right - an increase in tic severity can be expected. Moreover, behavioural abnormalities will likely also be exacerbated. First comes ADHD, present in 50-70\% of patients with GTS (Hirschtritt et al., 2015). In particular, the hyperactive phenotype makes confinement and quarantine hard to bear as physical energy cannot be released. It is also likely that rage attacks/explosive outbursts, as well as oppositional behaviour which largely depend on the presence of comorbid ADHD (Müller-Vahl et al., 2020) - will put an increasing strain on families. Reducing screen time - a frequent trigger of explosive outbursts - follows a paradoxical injunction similar to hand washing since it is more difficult to enforce in conditions of confinement and quarantine, added to which comes reduced schooling time. Yet, this is a potential conflict for parents as allowing children and adolescents to use screens more abundantly than usual may be the only way to keep the peace for the time being. Nevertheless, even in instances where increased screen time cannot be avoided, it is still possible to ensure that the content of what is being watched is age appropriate, engaging/ interactive and meaningful. With regard to ADHD and impulsivity, following the rules (hygiene and social distancing) may be particularly difficult. Note that behavioural abnormalities related to ADHD not only concern children but also adults, especially maladaptive behaviours (Haddad et al., 2009). Home schooling may further penalize children with learning disabilities, frequent in GTS. Lastly, a hallmark of GTS is individual variation. We have also heard from adult patients whose tics are usually worse when they are out in society and less intrusive at home; some have described being in self-isolation with families or alone and finding their tics relatively settled.

\section{Alterations in tics and behaviours specific to GTS}

As outlined in the two previous sections, many problems that patients with GTS face in the context of COVID-19 are related to their comorbidities, with an increase in tics the only outcome 
specific to their underlying disorder. However, certain nosographic features unique to GTS must also be considered.

Firstly, non-obscene socially inappropriate symptoms (NOSIS) (Eddy \& Cavanna, 2013; Kurlan et al., 1996) which lead patients to display behaviours at odds with what is socially acceptable and can also be referred to as provocative and transgressive.
Patients told us of developing new coughing tics, with a particular urge in public. Other examples to be expected in times of COVID-19 may manifest as spitting, sneezing into one's hands, not maintaining social distancing, or attempting to shake hands (personal observations). Touching other people is not an uncommon complex motor tic but in the "COVID-19 climate" could also represent NOSIS (see Table 1). Note that these

Table 1. Summary of the demography and clinical features of GTS and COVID-19.

\begin{tabular}{|c|c|c|}
\hline Clinical issues & Tourette syndrome & COVID-19 \\
\hline History & $\begin{array}{l}\text { Documented in the medical literature } \\
\text { since } 1800 \text { s and the symptomatology } \\
\text { has remained the same }\end{array}$ & $\begin{array}{l}\text { First described in China in December } \\
2019\end{array}$ \\
\hline Aetiology & $\begin{array}{cl}\text { Complex } \\
- & \text { Genetic } \\
- & \text { Birth difficulties } \\
- & \text { Immune factors }\end{array}$ & Viral infection - SARS-CoV-2 \\
\hline Infectious & Not at all & Highly \\
\hline Epidemiology & Worldwide & Worldwide \\
\hline Fatality & $\begin{array}{l}\text { Not per se } \\
\text { (but suicide rate is higher than in the } \\
\text { general population) }\end{array}$ & High (2-4\%) \\
\hline Age at onset & Young (peak 5-8 years) & Any ages affected \\
\hline $\begin{array}{l}\text { Age difference in severity of } \\
\text { symptoms }\end{array}$ & $\begin{array}{l}\text { Young people - mild on the whole } \\
\text { Severity reduces with age - even in } \\
\text { an individual }\end{array}$ & $\begin{array}{l}\text { Young and fit are usually mild } \\
\text { Worst severity in } \\
\text { - } \quad \text { Older people } \\
\text { - } \quad \text { People with cardiovascular/ } \\
\quad \text { metabolic risk factors) } \\
\text { - } \quad \text { Immune deficiencies }\end{array}$ \\
\hline $\begin{array}{l}\text { Clinical symptoms } \\
\text { (either mistaken for or pose } \\
\text { difficulties in a Covid-19 world) }\end{array}$ & $\begin{aligned} \text { Vocal tics } \\
-\quad \text { Coughing } \\
-\quad \text { Sniffing } \\
-\quad \text { Throat clearing } \\
\text { Motor tics } \\
-\quad \text { Eye blinking } \\
-\quad \text { Head nodding } \\
\text { Echopraxia/Palilalia e.g. copying } \\
\text { others (e.g. coughing) } \\
\text { Palilalia/Palipraxia - repeating action } \\
\text { or sound (e.g. coughing) } \\
\text { Forced touching of others }\end{aligned}$ & $\begin{array}{ll}\text { - } & \text { Dry cough } \\
\text { - } & \text { High Fever } \\
\text { - } & \text { Difficulty breathing }\end{array}$ \\
\hline $\begin{array}{l}\text { Clinical severity and impairment } \\
\text { Worse with comorbidity and } \\
\text { co-existent disorders and others } \\
\text { features }\end{array}$ & $\begin{array}{cl}\text { Comorbid } \\
-\quad \text { OCD/OCB } \\
-\quad \text { Autism } \\
-\quad \text { ADHD } \\
\text { Co-existent } \\
-\quad \text { Anxiety } \\
-\quad \text { Depression } \\
-\quad \text { Phobias } \\
\text { Other features important } \\
-\quad \text { NOSI } \\
-\quad \text { SIB }\end{array}$ & $\begin{array}{l}\text { Worst severity in those with } \\
\text { comorbid conditions, } \\
\text { especially } \\
\text { 1. respiratory } \\
\text { 2. cardio-vascular } \\
\text { 3. reduced immunity }\end{array}$ \\
\hline Management and treatment & $\begin{aligned} & \text { Complex with } \\
&- \text { Medication } \\
&- \text { CBT } \\
&- \text { DBS (rare) }\end{aligned}$ & $\begin{array}{ll}- & \text { Nil specific } \\
- & \text { Many agents tried } \\
\text { - } & \text { Severely ill patients require } \\
& \text { ICU and ventilators } \\
\text { - } & \text { Some assisted heart \& lung }\end{array}$ \\
\hline
\end{tabular}


behaviours can also fall into the risk-seeking/impulsive phenotype often present in patients with GTS (Wright et al., 2012). Furthermore, echolalia and echopraxia may lead patients with GTS to copy other people's coughing. In case of palilalia and palipraxia (repeating their last actions), a first 'real' cough may be repeated over and over again without any underlying respiratory need.

\section{Neurotropic effects of SARS-CoV-2}

To date, little is known about the potential neurological effects of SARS-CoV-2 but these have been suggested (Baig et al., 2020) and there is an evolving observation of high rates of anosmia and hypogeusia even in mild infection which may indicate neurotropism (Hopkins \& Kumar, 2020; Luers et al., 2020). Undoubtedly, this literature will grow over the upcoming months and years. As immune function may be altered (even though this does not necessarily mean diminished or compromised) in GTS, one may wonder whether our patients bear a special risk of sequelae. Intuition however dictates that this is highly unlikely as viral CNS infections have a higher probability to target people with neurodegenerative disease, or even causing it, as was the case after the Spanish influenza pandemic and resulting Encephalitis Lethargica (Hoffman \& Vilensky, 2017). In neurodevelopmental disorders such as GTS - and this also holds true for its comorbidities which are based on circuit dysfunctions - it is, at present, hard to see how a viral infection, and more specifically SARS-CoV-2, could lead to lasting CNS sequelae specific to GTS (for an evolving online resource, see here). However, only time will tell.

\section{Management and treatment}

Accurate recognition of the symptoms of coughing or sniffing as related to GTS as opposed to COVID-19 is critical in providing the right intervention and support. Similarly, spitting or forced touching etc. can be part of tic-related behaviours that may get the patient in trouble with the law. Hence awareness and appropriate support (e.g. the GTS patient may have to carry a card, informing authorities and other appropriate people about the condition) is important. Further, accurate identification and treatment of tics and comorbidities should continue as usual and according to established guidelines, if possible (Pringsheim et al., 2019). It is likely that medications will need to be increased probably transiently until the COVID-19 crisis resolves. That is obviously true for anti-tic medication as it is for psychostimulants (for ADHD) and selective serotonin reuptake inhibitors (for anxiety and OCD). There are currently unprecedented challenges in healthcare delivery and some of the specialists who would normally give this advice in many countries may be unavailable for a time due to redeployment, potentially causing further stress to families. Also, CBT for tics (van de Griendt et al., 2013) should be maintained by videoconferencing whenever possible (Andrén et al., 2019). The same applies to supportive psychotherapy for those who suffer from anxiety, depression, and loneliness. Finally, telehealth will play an increasing role in the medical follow-up of patients with TS, likely beyond the end of the pandemic. It will be important to establish whether this type of care will be well accepted by patients and families alike.
The National Patient Advocacy Groups for GTS in the UK and USA have published factual information and advice for individuals with GTS, their families and health-care professionals. These represent invaluable resources in their own right and, moreover, underline a sense of (global) community that is vital in these times.

Concerning the points raised above, we propose the following measures:

- Reduce media coverage to curb anxiety.

- Limit parental anxiety (or the expression thereof) as much as possible.

- In patients with contamination OCD, relax CBT rules in collaboration with the therapist. Insist that this is a temporary measure.

- Explain, if necessary, that tic increase does not reflect an aggravation of the primary disorder but is contextual, and thus transient.

- Reduce screen time reasonably (i.e. without triggering rage attacks and to avoid excessive boredom), but more importantly focus on the content of what is being watched.

- Use outdoor activities as much as possible and legally acceptable, especially when ADHD is present, or engage in activities that can be done indoors.

- Insist on upholding current rules (hygiene, social distancing) firmly but also gently.

- If patients get in conflict with the law or just other individuals because of NOSIS, echo- or palipraxia (i.e. abundant coughing in public or displaying at-risk behaviours), attempts should be made to resolve the issue by explaining these symptoms. In some cases, "urgency cards" can also be of great help (see here and here).

- For health-care professionals: keep up outpatient clinics by telephone or videoconferencing as much as possible. The latter may prove useful even after the pandemic will have abated.

- Finally, there are no indications that SARS-CoV-2 infections might lead to central nervous system sequelae for patients with GTS in the intermediate or long term. Neither does GTS alone put individuals in a higher risk group for general consequences of infection. If necessary, reassurance is needed in this matter.

\section{Conclusion}

GTS, as a complex neuropsychiatric disorder, offers many angles of attack for the current COVID-19 pandemic and its consequences (social distancing, home schooling, confinement/quarantine, and living in a general climate of fear). Also, some patients might expose themselves to social conflict because of behavioural features specific to GTS. Thus, they need our reassurance and help in these difficult times, supported by a network of informed health-care professionals, although already rare in 'normal' times. Ideally, 
specialist medical services will be able to organise in the face of acutely changing roles in hospitals to provide advice when needed, to avoid a feeling of professional abandonment (which obviously is not special to patients with GTS). With this short paper, we hope to have contributed a few small pieces to the puzzle which will hopefully help us navigate through the upcoming weeks and months.

\section{Data availability}

No data are associated with this article.
APA: Diagnostic and Statistical Manual of Mental Disorders (DSM-5). Washington: American Psychiatric Association; 2013.

Reference Source

Andrén $\mathrm{P}$, Aspvall $\mathrm{K}$, Fernández de la Cruz $\mathrm{L}$, et al:: Therapist-guided and parentguided internet-delivered behaviour therapy for paediatric Tourette's disorder: a pilot randomised controlled trial with long-term follow-up. BMJ Open. 2019; 9(2): e024685.

PubMed Abstract | Publisher Full Text | Free Full Text

Baig AM, Khaleeq A, Ali U, et al:: Evidence of the CoVID-19 Virus Targeting the CNS: Tissue Distribution, Host-Virus Interaction, and Proposed Neurotropic Mechanisms. ACS Chem Neurosci. 2020; 11(7): 995-998.

PubMed Abstract | Publisher Full Text | Free Full Text

Brooks SK, Webster RK, Smith LE, et al.: The psychological impact of quarantine and how to reduce it: rapid review of the evidence. Lancet. 2020; 395(10227): 912-920.

PubMed Abstract | Publisher Full Text

Eapen V, Cavanna AE, Robertson MM: Comorbidities, Social Impact, and Quality of Life in Tourette Syndrome. Front Psychiatry. 2016; 7: 97.

PubMed Abstract | Publisher Full Text | Free Full Text

Eddy CM, Rizzo R, Gulisano M, et al.: Quality of life in young people with

Tourette syndrome: a controlled study. J Neurol. 2011; 258(2): 291-301.

PubMed Abstract | Publisher Full Text

Eddy CM, Cavanna AE: On being your own worst enemy: an investigation of socially inappropriate symptoms in Tourette syndrome. J Psychiatr Res. 2013; 47(9): 1259-63.

PubMed Abstract | Publisher Full Text

Elstner K, Selai CE, Trimble MR, et al:: Quality of Life (QOL) of patients with Gilles de la Tourette's syndrome. Acta Psychiatr Scand. 2001; 103(1): 52-9. PubMed Abstract | Publisher Full Text

Freeman RD, Zinner SH, Müller-Vahl KR, et al:: Coprophenomena in Tourette syndrome. Dev Med Child Neurol. 2009; 51(3): 218-27.

PubMed Abstract | Publisher Full Text

Haddad AD, Umoh G, Bhatia V, et al:: Adults with Tourette's syndrome with and without attention deficit hyperactivity disorder. Acta Psychiatr Scand. 2009; 120(4): 299-307.

PubMed Abstract | Publisher Full Text

Hopkins C, Kumar N: Loss of sense of smell as marker of COVID-19 infection. Reference Source

Hirschtritt ME, Lee PC, Pauls DL, et al.: Lifetime prevalence, age of risk, and genetic relationships of comorbid psychiatric disorders in Tourette syndrome. JAMA Psychiatry. 2015; 72(4): 325-33.

PubMed Abstract | Publisher Full Text | Free Full Text

Hoffman LA, Vilensky JA: Encephalitis lethargica: 100 years after the epidemic. Brain. 2017; 140(8): 2246-2251.

PubMed Abstract | Publisher Full Text

Lüers JC, Klußmann JP, Guntinas-Lichius O: [The Covid-19 pandemic and otolaryngology: What it comes down to?] Laryngorhinootologie. 2020. PubMed Abstract | Publisher Full Text

Kandeel M, Ibrahim A, Fayez M, et al:: From SARS and MERS CoVs to SARSCoV-2: Moving toward more biased codon usage in viral structural and nonstructural genes. J Med Virol. 2020

PubMed Abstract | Publisher Full Text

Kurlan R, Daragjati C, Como PG, et al:: Non-obscene complex socially inappropriate behavior in Tourette's syndrome. J Neuropsychiatry Clin Neurosci. 1996; 8(3): 311-7.

PubMed Abstract | Publisher Full Text

Mao L, Wang M, Chen S, et al.: Neurological manifestations of hospitalized patients with Covid-19 in Wuhan, China: a retrospective case series study.

MedRxiv Preprint. 2020.

Publisher Full Text
Martino D, Ganos C, Pringsheim TM: Tourette Syndrome and Chronic Tic Disorders: The Clinical Spectrum Beyond Tics. Int Rev Neurobiol. 2017; 134: 1461-1490.

PubMed Abstract | Publisher Full Text

Martino D, Zis $P$, Buttiglione M: The role of immune mechanisms in Tourette syndrome. Brain Res. 2015; 1617: 126-43.

PubMed Abstract | Publisher Full Text

Müller-Vahl KR, Kayser L, Pisarenko A, et al:: The Rage Attack QuestionnaireRevised (RAQ-R): Assessing Rage Attacks in Adults With Tourette Syndrome. Front Psychiatry. 2020; 10: 956.

PubMed Abstract | Publisher Full Text | Free Full Text

Pringsheim T, Okun MS, Müller-Vahl K, et al.: Practice guideline recommendations summary: Treatment of tics in people with Tourette syndrome and chronic tic disorders. Neurology. 2019; 92(19): 896-906. PubMed Abstract | Publisher Full Text | Free Full Text

Rizzo R, Gulisano M, Pellico A, et al:: Tourette syndrome and comorbid conditions: a spectrum of different severities and complexities. J Child Neurol. 2014; 29(10): 1383-9.

PubMed Abstract | Publisher Full Text

Robertson MM, Cavanna AE: The disaster was my fault! Neurocase. 2007; 13(5): $446-51$.

PubMed Abstract | Publisher Full Text

Robertson MM, Eapen V, Singer HS, et al: Gilles de la Tourette syndrome. Nat Rev Dis Primers. 2017; 3: 16097.

PubMed Abstract | Publisher Full Text

Towers VS, Goldsmith M, Goldsmith P: Zika Virus: Patient Education

Recommendations. Adv Neonatal Care. 2018; 18(5): 360-365.

PubMed Abstract | Publisher Full Text

van de Griendt JM, Verdellen CW, van Dijk MK, et al.: Behavioural treatment of tics: habit reversal and exposure with response prevention. Neurosci Biobehav Rev. 2013; 37(6): 1172-7.

PubMed Abstract | Publisher Full Text

Wan S, Xiang Y, Fang W, et al.: Clinical Features and Treatment of COVID-19 Patients in Northeast Chongqing. J Med Virol. 2020.

PubMed Abstract | Publisher Full Text

Wright A, Rickards H, Cavanna AE: Impulse-control disorders in Gilles de la Tourette syndrome. J Neuropsychiatry Clin Neurosci. 2012; 24(1): 16-27. PubMed Abstract | Publisher Full Text

Wu F, Zhao S, Yu B, et al.: A new coronavirus associated with human respiratory disease in China. Nature. 2020; 579(7798): 265-269. PubMed Abstract | Publisher Full Text | Free Full Text

Zhang G, Zhang J, Wang B, et al: Analysis of clinical characteristics and laboratory findings of 95 cases of 2019 novel coronavirus pneumonia in Wuhan, China: a retrospective analysis. Respir Res. 2020a; 21(1): 74 PubMed Abstract | Publisher Full Text | Free Full Text

Zhang JJ, Dong X, Cao YY, et al.: Clinical characteristics of 140 patients infected with SARS-CoV-2 in Wuhan, China. Allergy. 2020b.

PubMed Abstract | Publisher Full Text

Zhang X, Cai H, Hu J, et al:: Epidemiological, clinical characteristics of cases of SARS-CoV-2 infection with abnormal imaging findings. Int J Infect Dis. 2020c. PubMed Abstract | Publisher Full Text

Zheng F, Liao C, Fan QH, et al:: Clinical Characteristics of Children with Coronavirus Disease 2019 in Hubei, China. Curr Med Sci. 2020a. PubMed Abstract | Publisher Full Text

Zheng HY, Zhang M, Yang CX, et al:: Elevated exhaustion levels and reduced functional diversity of T cells in peripheral blood may predict severe progression in COVID-19 patients. Cell Mol Immunol. 2020b. PubMed Abstract | Publisher Full Text

Zhu N, Zhang D, Wang W, et al.: A Novel Coronavirus from Patients with Pneumonia in China, 2019. N Engl J Med. 2020; 382(8): 727-733. PubMed Abstract | Publisher Full Text | Free Full Text 


\section{Open Peer Review}

\section{Current Peer Review Status:}

\section{Version 2}

Reviewer Report 28 April 2020

https://doi.org/10.5256/f1000research.26007.r62824

(C) 2020 Cavanna A. This is an open access peer review report distributed under the terms of the Creative Commons Attribution License, which permits unrestricted use, distribution, and reproduction in any medium, provided the original work is properly cited.

\section{Andrea Cavanna}

Department of Neuropsychiatry, BSMHFT, University of Birmingham, Birmingham, UK Approved.

Competing Interests: No competing interests were disclosed.

Reviewer Expertise: Behavioural neurology and neuropsychiatry.

I confirm that I have read this submission and believe that I have an appropriate level of expertise to confirm that it is of an acceptable scientific standard.

\section{Version 1}

Reviewer Report 17 April 2020

\section{https://doi.org/10.5256/f1000research.25696.r62277}

(C) 2020 Cavanna A. This is an open access peer review report distributed under the terms of the Creative Commons Attribution License, which permits unrestricted use, distribution, and reproduction in any medium, provided the original work is properly cited.

\section{Andrea Cavanna}

Department of Neuropsychiatry, BSMHFT, University of Birmingham, Birmingham, UK

This is a timely, informative, and well written article providing clinicians with practical advice about how to best advise and support patients with tics during these challenging times. The authors navigate through the many uncertainties of the unfolding circumstances using the best available evidence as well as their own invaluable experience, according to the ancient motto 'scientia et 
conscientia'.

I have little to say in terms of further improving this useful article. As the authors rightly point out, anxiety is a common comorbidity that needs to be addressed with particular care, in consideration of its recognized role as tic-exacerbating factor.

A recent review article on telemedicine for hyperkinetic movement disorders covers tic disorders, and states that "the extent to which telemedicine facilitates multidisciplinary treatment needs to be further studied" (Srinivasan et al. 2020) ${ }^{1}$. It is hoped that the current circumstances and the unprecedented measures (including social distancing) are also seen as an opportunity to improve our understanding of patients' needs. The authors might want to add their suggestions about gathering high quality information on remotely delivered clinical input.

\section{References}

1. Srinivasan R, Ben-Pazi H, Dekker M, Cubo E, et al.: Telemedicine for Hyperkinetic Movement Disorders.Tremor Other Hyperkinet Mov (N Y). 2020; 10. PubMed Abstract | Publisher Full Text

Is the topic of the opinion article discussed accurately in the context of the current literature?

Yes

Are all factual statements correct and adequately supported by citations? Yes

Are arguments sufficiently supported by evidence from the published literature? Yes

Are the conclusions drawn balanced and justified on the basis of the presented arguments? Yes

Competing Interests: No competing interests were disclosed.

Reviewer Expertise: Behavioural neurology and neuropsychiatry.

I confirm that I have read this submission and believe that I have an appropriate level of expertise to confirm that it is of an acceptable scientific standard.

Reviewer Report 16 April 2020

https://doi.org/10.5256/f1000research.25696.r62276

(C) 2020 Müller-Vahl K. This is an open access peer review report distributed under the terms of the Creative Commons Attribution License, which permits unrestricted use, distribution, and reproduction in any medium, provided the original work is properly cited.

Kirsten R Müller-Vahl

Clinic of Psychiatry, Social Psychiatry and Psychotherapy, Hannover Medical School, Hannover, 


\section{Germany}

This is a nicely written paper by a group of renowned European Tourette experts about GTS in times of COVID-19. The authors discuss similarities of COVID-19 and tics in GTS and outline specific problems that may result from the pandemic for this group of patients. Finally, they give concrete suggestions how to advice and treat patients with GTS and their families during the pandemic. I like this small paper and find it interesting to read, since it alerts us that the current pandemic may be much more challenging for patients with GTS compared to healthy people. I have some minor suggestions the authors may take into consideration to further improve the quality of this manuscript:

The authors mix the name of the virus (SARS-CoV-2) and the name of the disease caused by this virus (COVID-19). COVID-19 is simply the abbreviation of Coronavirus Disease 2019. Therefore, the authors should correct for example the heading "Aetiology: COVID-19 (coronavirus)". As far as I know, the correct spelling is "SARS-CoV-2" (not "SARS-Cov-2"). Also in Table 1: "Viral infection - Coronavirus 19" please change in "SARS-CoV-2".

The authors describe the different symptoms associated with COVID-19 including neurological complications. I suggest to include recent reports on meningitis/encephalitis (for example see: https://doi.org/10.1016/j.ijid.2020.03.062)1.

Coprolalia: according to the literature it occurs in more than $10 \%$ of patients. I suggest to include a reference here too.

The authors should use the term "pandemic" throughout instead of in some cases "epidemic".

Correct "cognitive-behavioural (CBT) training" in "cognitive-behavioural training (CBT)".

Rephrase this sentence (I think the "a" must be deleted): "Touching other people is a not an uncommon complex motor tic but in the "COVID-19 climate" could also represent NOSIS (see Table 1)."

Table 1: I suggest to spell "Palilalia/Palipraxia" and "Echo praxia - lalia" in the same way.

I suggest to change the order: "selective serotonin reuptake inhibitors (SSRIs)" instead of "SSRIs (selective serotonin reuptake inhibitors)".

\section{References}

1. Moriguchi T, Harii N, Goto J, Harada D, et al.: A first Case of Meningitis/Encephalitis associated with SARS-Coronavirus-2. International Journal of Infectious Diseases. 2020. Publisher Full Text

\section{Is the topic of the opinion article discussed accurately in the context of the current} literature?

Yes

Are all factual statements correct and adequately supported by citations? 
Yes

Are arguments sufficiently supported by evidence from the published literature?

Yes

Are the conclusions drawn balanced and justified on the basis of the presented arguments? Yes

Competing Interests: No competing interests were disclosed.

Reviewer Expertise: Tourette syndrome, tic disorders, cannabis-based medicine

I confirm that I have read this submission and believe that I have an appropriate level of expertise to confirm that it is of an acceptable scientific standard.

\section{Comments on this article}

\section{Version 2}

Reader Comment 12 May 2020

Bill Li, freelance, Beijing, China

very good

Competing Interests: none

\section{Version 1}

Author Response 17 Apr 2020

Andreas Hartmann, Groupe Hospitalier Pitié-Salpêtrière, Paris, France

We thank Prof. Müller-Vahl and Prof. Cavanna for their reviews and have incorporated all their comments into version 2 of the paper with one exception: this concerns citing reports on neurologic complications of COVID-19. For now, we prefer to stick to the AAN resource centre link we provided since this is a rapidly moving field, and will likely provide a more panoramic view of the field. Also, it is at present unclear to what extent these complications are causally linked to COVID-19 or correlational, so care is warranted.

Competing Interests: N/A 
The benefits of publishing with F1000Research:

- Your article is published within days, with no editorial bias

- You can publish traditional articles, null/negative results, case reports, data notes and more

- The peer review process is transparent and collaborative

- Your article is indexed in PubMed after passing peer review

- Dedicated customer support at every stage

For pre-submission enquiries, contact research@f1000.com 